\title{
JTE
}

Journal of Teachers of English

Volume 5 No. 2, 2020

e-ISSN: 2548-6810

\section{THE ADDRESS TERMS OF BUGIS LANGUAGE IN KOMBA-KOMBA VILLAGE KABANGKA DISTRICT MUNA REGENCY}

\author{
Asriani $^{1}$, Aderlaepe ${ }^{2}$, La Ode Nggawu ${ }^{3}$
}

1,2,3 Halu Oleo University, Indonesia.

\begin{tabular}{l} 
ARTICLE INFO \\
\hline Keywords: \\
Address Terms, Bugis \\
Language \\
How to cite: \\
DOI:
\end{tabular}

\begin{abstract}
The objective of this study this research is to describe the forms of the address term of Bugis language In Komba-Komba Village Kabangka District Muna Regency. The method used in this research is descriptive qualitative analysis by using some techniques of collecting data such as: 1) Observation, 2) Elicitation, 3) Recording and 4) Noting. After the data being collected, the researcher analyze the following steps: 1) Transcript the data, 2) Making classification of gather data relating to greeting term, 3) Making description for last generalization objectively based on the script of data found in the field of the research. Data analysis in this research was analyzed by a functional grammar approach (Halliday, 1985) namely Field, Tenor, and Mode. The scope of this research is limited by the use of address term of Bugis language which is used in the circle of the family according to society that occurred in the formal and informal situation. The result of this research showed the address terms of Bugis language has three forms of the address term namely: 1) Address terms in Family 2) Address terms in Community 3) Address terms based on position (noble).
\end{abstract}

\section{Introduction}

The phenomenon of the speech of the existing community, especially in the Bugis community, is inseparable from the aspects of language usage, one of which is the greeting terms of bilingual language and politeness in the language. Language politeness, especially in traditional Bugis communities, has been governed by the norms and morality of its people, which are internalized in the context of local culture and wisdom, both through folklore and through oral traditions such as "Pappaseng and Elong Ugi". the pattern of behavior between the Bugis community in the form of verbal communication has been long-lived and realized until now, although it must be understood that all ethnic and ethical behavior are relative, depending on socio-cultural factors and the familiarity of the speakers and hermit (Agus, 2010: 2).

Some sociopragmatic scholars have expressed the importance of using politeness in language, besides because it serves to perfect one's language 
structure. In sociolinguistic studies, a greeting is one form of linguistic marker that is very influential on the use of verbal language. According to Crystal (1987: 120) pragmatics studies the factors that govern our choice of language in social interaction and the effect of our choice on others. In theory, we can say anything we like. In practice, we follow a large number of social rules (most of them unconsciously) that constrain the way we speak. Pragmatics is defined as conditions that result in the harmonious use of language in communication; aspects of the use of language or context outside the language that contributes to the meaning of speech (Kridalaksana, 1993: 177).

That Phenomenon can be a benchmark for the author to examine the behavior of language for the Bugis community in the Komba-Komba Village Kabangka District Muna Regency, especially said women and men. In this case will be examined address terms/form of greeting used in the language Bugis and behavior tells the public, especially in terms of use of the word hello used by speakers of women and men. It is believed that the use of greetings between women and men will give different nuances of speech behavior.

A woman's language behavior will be different when speaking to a fellow woman to a male counterpart. A native speaker who has a younger age will choose a different form of greeting when speaking to older male or female protégés. Similarly, a female speaker or a man with social status will choose a different greeting form when speaking to a woman or man who has the same or lower social status. The language behavior of the two groups represents the greeting as a linguistic requirement, in addition to their high positive attitudes toward the use of good, proper, and polite language, as well as the demands to apply the basic concept of Bugis society, namely the preoccupation of the concept of humanizing each other or "Mappakatau".

This phenomenon indirectly describes the behavior of speakers of women who prefer the positive nature of the use well of Bugis language, correct and polite. The attitude of Bugis native speakers at the same time indicates the amount of attention and their efforts in terms of guidance of polite language behavior, especially to children, families, and surrounding communities. Also besides, Bugis speakers also always show and solidarity towards polite language behavior (Agus, 2010: 215). In some cases, Bugis speakers will choose a more polite form of social greeting because can to minimize the risk of the hermit as well as strengthen solidarity relationships among participants. On the other hand, women speakers always show good, correct and polite language behavior, both to children, husbands, parents, and the general public.

Based on the background description, the present research conducted to answer the following questions "What is the address terms of Bugis language that used in Komba-Komba Village Kabangka District Muna Regency?"

\section{Sociolinguistic}

The sociolinguistic is derived from two elements namely socio and linguistic. Socio is the way of social interaction among people that is the relation between community and social function. Afterward, Linguistic is a study of language, especially the language elements, including the essence and formation of those 
elements. So it can be said that sociolinguistic is a study about language in connection with the narrator of the language as one of the community members. Hickersen (in Yuliana 2005:11) states that sociolinguistic is a developing subfield of linguistic which takes speech variation as its focus, viewing variation or its social context sociolinguistic is concerned with the correlation between such social factors and linguistic variation.

On a simple scale, sociolinguistic explains the relationship between language usage and social behavior. To explain the usage of language events, someone can know various conditions, confidence values, and the values which form and give characteristics to the language use of the social groups.

Also sociolinguistic analyzes the language which is used by someone with all its delivery, include the small case, such as symbol like words or signals which states that he/she is paying attention seriously, agree and disagree, moreover including realize his/her position when he/she speaks with the others people.

Furthermore, Nababan (in Yuliana 2005:11) scopes the sociolinguistic into three aspects as follows:

1. Analyzing the language used in the social and cultural context

2. Combining the language factors and language variety with the situational and socio-cultural factors.

3. Analyzing the social functions and language use in society.

According to Fishmen (in Yenni Wabula 2005:7) Sociolinguistic is defined as a science that studies about feature functions of all sort of language variation and it's the relation among the linguistic with that feature and function in a language society. It clearly shows that sociolinguistic doesn't only focus on language phenomena. But also focus on social behavior, language attitude, real behavior toward language and language user.

Based on the explanations above, the researcher can conclude that sociolinguistic is a branch of linguistic which consists of two interdisciplinary sciences, namely sociology and language. It means that it explains the language event in relation to social behavior and social culture.

\section{Address Term}

Term of address is greeting made by someone when overflowing, conversation with others, either both or among of the speakers include in generation relationship or not. The term address is determined by several factors such as gender, social status or position, precise, norm, and family relation. The use of address forms is adjusted with the conventions that exist in that community, every language has a set of address form and the use of it only for the certain community.Tanner in Yenni Wabula (1986:22) states that in language behavior, naturally speaker have decided to select a certain variation of linguistic forms the taking of decision actually pass the process that determined by factors such as social status, situation, and topic of talking while Ervin-Trip(1985:5) states that the factors that give of color in greeting are called selector term in sociolinguistics. The address in the Indonesia language is Sapaan. Sapaan comes from basic word of sapa, it means the words to conversation and then gets the suffix-an, become Sapaan, Sapaan it's mean the invitation of conversation (Depdikbud, 1988:849). 
According to Kridalaksamana (in Kamal 1990: 7) states that "the greeting is a morpheme, word, or phrase used to refer to each other in different situations of conversation and according to the nature of the relationship between the talks". While the form of a greeting is a set of words or phrases used to call and summon the perpetrators in a language event. The perpetrators here are the speakers (perpetrator one), who are invited to speak (the second actor), and who is mentioned in the conversation (the third offender). The form of the greeting can be either pronoun, name of self, words are exchanged or indicator, nominal (zero or zero characters).

Tanner (in Abu jalil, 2001: 9) states that "in the act of language, in essence, a speaker has decided to choose a particular variation in the form of linguistic forms. Decision-making is actually through a process that is determined by various determining factors is social distance, situation, and topic of conversation"

Form of address is established by some factors such as gender, ages, position, polite appreciation and having to do with the family. The used of address forms based on a conversation which is valid in the community. Every language knows a set of address form that its use limited on the community of language used. (Robinson in Abu jalil, 2001:10). While Coort (in Abu jalil, 2001:10) states that "The system of etiquette affects the relationship of the speaker with the audience in the family as well as in society".

Based on the opinions above, the researcher concludes that address is a set of words expression which is used to mention and to call the actors of language events. The form of address which was used is determined by age, gender, position, family relationship, situation and the topic of conversation between the speaker and listener.

\section{Factors That Influence Address Term}

The form of address is determined by several factors such as gender, social, status or position, precise and family relation. The use of address form is adjusted with the conventions that exist in that community. Every language has a set of address forms and the use of it only for a certain community. According to (Aslinda and Noviantry,2000:7) in their study about address terms in Minangkabau of Agam Regency stated that there are some factors that influence the address word they are (1) education, (2)gender or sex, (3) profession, (4)age, and (5) social status.

4. Forms of Address Term

A form of address is a set word or expression used to mention and call people in a language event. According to kridalaksana (in Yenni Wabula 2005:15) states that the use of address form depends on convention or agreement of the speech community or the user of the language, since the conventional in character hence a linguist or certain institute cam to determine or force of a certain word to be used in a language.

Every language has a form of address that different from other address forms. An example in Iban language, the form of address will be different from the address form of Melayu Sambas. For addressing father, the address which was 
used in Iban language is "apai" while in Melayu Sambas is "ayah". It was caused by language background and culture from both of those societies. Nevertheless, there is also some language that has similar certain address term in addressing mother, for example, Bugis language uses "indo" that means is "Ibu". It may also happen in some language that occurs in southeast Sulawesi province particularly.

In connection with the importance of language, Brown (in Yuliana 2005:2) divided two views of language functions, namely: transactional view and interactional one. Based on the transactional view means they suppose that language may be used to perform many communicative function, they nonetheless male the general assumption that the most important is communication of information on the other hand, based on the interactional view they suppose that language is used to establish and maintain social interaction. In this case, language is used to negotiate of face of both speaker and listener.

Realize to the function and the position of regional language in connection with establishment and developing of regional language, so the language in archipelago necessary to be save threat of extinction. It is supported by wisdom of government which was recorded in the explanation of Undang-Undang Dasar 1945 section 36 which is stated that the vernacular which is still used in the community such as Javanese, Sundanese, and Balinese etc. should be kept because they are a part of Indonesian culture.

The function and the position of vernacular has been formulated in the Political National Language (Halim, 1980:147). It is stated that vernacular has a lot of functions in our country, namely: (1) as a regional pride, (2) as a regional identity, (3) a medium of communication in the family and in the society, and (4) as a medium of supporting and developing regional culture.

Relating to above description, the researcher thinks that it is still necessary to teach and investigate the regional languages in Indonesia. This opinion is based on the consideration that the regional language has very important role in daily social activities of their speech community and they can also help the development and enrichment of Indonesia language.

The researcher is sure that every language has different terms used by the speaker its speech community in giving an address to their interlocutors. The use of address terms in the speech community will be happened in their family, their society, their institution or office, moreover in the educational institution therefore, the communicative situation and relationship between speaker and interlocutor has an important role in determining the address terms should be used. Based on the survey result in Komba-Komba village, Kabangka district at Muna regency, the native speakers of Bugis language of Bone dialect is about $70 \%$ from all native speakers of Bugis language who live in Tanjung Batu village and $30 \%$ another ethnic group. 
There are several reasons for doing this research; first, the author is a native speaker of Bugis. Therefore, the authors have a responsibility to improve and develop regional languages as part of Indonesian culture, secondly Indonesian language itself is threatened with extinction of the use of this Bugis language teenagers have been reduced and rarely use their own local language, regional languages continue to lose because it needed ancient and plebeian, that's a real phenomenon among modern society today. The author thinks is an important language unity that should be mastered by learners and language users because it is often used in everyday communication, especially the language Bugis itself. Currently the flow of globalization is very influential in the development of the modern world. The modern world that every second has always had an impact and effect on today's life, especially for teenagers, the age of globalization has managed to change the lifestyle of today's teens ranging from life, language, clothing, interests, and so on. Speaking of language, the current fact is that most of the teenagers master a foreign language rather than the language of their own region, as an example of today's bizarre teenagers, most of those who master foreign languages such as English, Korean, Chinese, German, and Japanese rather than Bugis language itself. Some adolescent Bugis assume that everyday interactions in the Bugis language the same as Kamseupay, or often called less slang, not modern, and plebeian. Though the local culture itself is very necessary to be improved and preserved so that the characteristics and character of the area itself remains and appears from foreign cultures.

In the development of the current Bugis language, there is an imbalance between the language Bugis and foreign language that began creeping on the Bugis community. How come? Nearly $80 \%$ every day Bugis teenagers interact through the Indonesian language and some are using English because of the demands of the formal party. This is not to blame because the Indonesian language is very instrumental in the wider world of social relationships such as within the State of Indonesia itself, and also the English language is an international language that connects communication in the international sphere. But it does not mean that the Bugis language, the traditional language of the Bugis culture that should sink just because of a foreign language that has spread among the Bugis community itself.

The saddest fact among teenagers is the sense of pride and shame for the current Bugis adolescent in using the local language in communicating especially Bugis language. Indeed, today is a modern era that demands to lead to the modern and in accordance with the development of technology and communication, but not also rule out the Bugis language that has become the culture down the ancestors of the ancestors. The uniqueness of this research aside from the place of research is the result of the research itself, that is, there is no influence on the form of greeting in the Bugis community itself but there is an influence on the structure of the sentences such as the word "dewenni" which should be" addressed "Nappanna" which is supposed to be "appanna", the influence of this language is due to the Absorption of Foreign Languages or 
Languages of the Muna, Absorption of foreign languages and the languages of the archipelago is one factor to increase the new word in Bugis language. The process of absorption or borrowing is carried out directly from the source language. Then the existence of the Muna language relation to the Bugis language so that the occurrence of language literacy. is mentioned in the Thesis in Sitti Alijah 2016 with the title (Kekerabatan Bahasa Bugis Dan Bahasa Muna).

\section{Methodology}

In this study, the design of the research is qualitative descriptive. The researcher describes the address terms in Bugis language based on data that is got to the field by recording the speech event directly. Herewith, the researcher tries to explain the concepts, is used the words or sentence and not used numerals of statistic in a certain structure that logic and used comprehension that deepens. It's has proposed appropriate the fact that is got in the data of research.

The data used by the researchers in this study is oral language data. Oral language data is derived from the interaction of the local Bugis society in the form of speeches in sentence form and words containing Bugis speech words spoken by native Bugis speakers by following the context of the conversation. A source of data in this study comes from the Bugis community or a group of people who interact in everyday life in Komba-Komba village Kabangka District Muna regency, as native speakers of the language Bugis both in the family environment and society, a group of people in question who are domicile in Komba-Komba village. This study is based on the consideration that this area especially the coastal part is generally inhabited by Bugis people in this village who use the Bugis language in everyday life. In the study of language, the retrieval of some informants can be justified, because all languages used apply the same system. If not the same must be the speakers will not understand or the second and third parties consider the first party to deviate from the system that is caught.

In instrument of the data, the researcher used techniques as follows:

1. Observation, it was done by visiting the object of the research place directly for obtaining data about the address term that was used by the speakers.

2. Elicitation. It is used by giving questions to the informants directly and efficiently.

3. Recording, it was done by recording directly the speech event field.

4. Noting, it was done by noting the speech event it the field.

Technique of Data Analysis, For knowing the address terms that are used, the data were analyzed by functional grammar approach (Halliday, 1985), namely the way that is usually used in analyzing the speech event based on the context of conversation that consist of field, tenor and mode though a number of steps as follows:

1. Transcript the data

2. Making classification of gather data relating to address terms, the researcher classified the address terms based on who used the address terms to whom and when. 
3. Making description objectively based on the script of data found in the field of the research, the researcher described the using of address terms based on the participant interaction, setting, and how the address terms used between parents and children, children and children, husband and wife, this description includes factors that might dictate the use of address terms.

4. Categorization

1. Address terms in Family

2. Address terms in Community

3. Address terms based on position (noble)

\section{Result and Data Analysis}

Based on the result of the research which was clarified on discussion, the researcher will conclude as follows:

1. The address terms in Bugis language which is used in the family context there are fourteen kinds of address terms usually used namely:

a) Lato' is an address term used by a grandchild to his or her grandfather

b) Nene' is an address term used by a grandchild to his or her grandmother

c) Ambo/Ambe is an address term used by a child to his or her father

d) Indo/Emma is an address term used by a child to his or her mother

e) Daeng is an address term used by younger brother/sister to his older brother/sister

f) Andri is an address term used by older brother/sister to his younger brother/sister

g) Eppo' is an address term used by grandmother to his or her grandchild

h) Ma'na is an address term used by a Husband to his wife

i) Pa'na is an address term used by a Wife to her husband

j) Om is an address term used by nephew or niece to his or her uncle

k) Tanta is an address term used by a nephew or niece to his or her aunt

1) Sappuseng is an address term used by a cousin to cousin

m) Annure is an address term used by aunt or uncle to his or her nephew or niece

n) Ammure is an address term used by nephew or niece to his or her uncle or aunt.

2. The address terms in Bugis language which is used in community namely:

a) Ma'na Or Pa'na is an address term used by a neighbor to neighbor. Ma'na or Pa'na Means mother of/father of for example Ma'na Adha lokka ri pasa'e, Pa'na Adha lokka ri tasi'e (Adha's mother go to the market, Adha Father go to the sea).

b) Silo' is an address term used by a friend to friend

3. Address terms based on position (noble)

The form address term of Puang or Andi is used to greet older people or people who have higher social status

a) Puang is an address term used by people who have tittles in the community or religion 
b) Andi is an address term used by people who have noble tittles in the community. Andi means young nobility.

\section{Discussion and Conclusion}

There is one question needed to be answered. The question is What is the address terms of Bugis that used in Komba-Komba Village Kabangka District Muna Regency?

The result of this study shows that address terms of Bugis that used in Komba-Komba Village Kabangka District Muna Regency. For the Bugis community, greet someone especially family members using the word greeting, In addition to hanging the speech according to the norm "ade" "makkeada-ada", also to maintain good relations between family members. Family greetings as speech style markers are used more by female speakers than men (Agus 2010:6)

In the family realm, age is one of the determinants of greeting election for female and male speakers. The greeting option to older greeters differs from the greeting option to the same-age or younger-than-happier greeters. This becomes important; given the Bugis community is very concerned about self-esteem, as part of family members. In addition, they strongly prioritize and maintain kinship and solidarity relationships, female hermits and male Bugis usually do not use the direct name greeting, but choose to use other forms of greeting, especially expressed by the adult hermit, who have the same level of power or more low from it. in general the two groups are more often use some form of greeting that is adjusted to the position of the family member.

The address terms in the internal family is used to show vertical relationship between speaker and listener or between the speaker and someone who are talked. It can also be said that this address term are used by the people who have brotherhood relationship directly, for example: grandfather, grandmother, father, mother, and son. Furthermore, how they greet each others are automatically depended on the condition of family relationship.

Language is used by human beings to express his/her feeling and desire, With language people can cooperate, interact, and identify them. Badudu (in Emi Satriana 2008:7). Language is system of sign that related with symbol of sound, and it was used by a group of community to communicated and work together Barber (in Abu jalil, 2001:11). The other specialist states that "language can also define as a symbol system of sound that arbiter which was used by member of community as a tool to interact according to their culture Trager (in Abu jalil, 2001:11)". Furthermore, according to While (In Abu Jalil, 2001: 11) in linguistic dictionary stated that language is a symbol system that arbitrate which was used by community to work together, and to interact. 
Based on the results and the above scientist opinions, it can be concluded that language is a system that used by human being or community to communicate the idea, thought, and feeling. Language take hold an important role as a tool of interaction and every things of communication which was done by human being. Indonesian society have two class seen of the use of language namely there are society who used regional language in their life and also there are society who used Indonesian language in their life.

\section{References}

Abu Jalil. 2001 The Addressing Terms In Muna Language (Tongkuno Dialect). Unpublished Thesis.

Agus, Nuraidar.2010."Perilaku Berbahasa Antara Wanita Dan Pria: Fenomena Perbedaan Berbahasa Berdasarkan Sosiokultural". Jurnal Terakreditasi Sawerigading, Issn 0854-4220, Vol. 16 Edisi Khusus, Agustus 2010( Hlm.214-223) 2013."Bentuk Kesantunan Linguistic Dan Stratgi Pertuturan Wanita Dan Pria Etnis Bugis". Disertai Belum Diterbitkan. Universitas Hasanuddin; Program Pasca Sarjana.

Amirin, M. Tatang. 1989. Pokok-pokok Teori Sistim. Jakarta. CV. Rajawali

Amir, Johar. "Sapaan Dalam Bahasa Bugis Dialek Sidrap." Masyarakat Linguistik Indonesia (2011): 69.

Arif Rahman. 2014 "Affix Derivation Buginese Palakka Dialect". Unpublished Thesis.

Aslinda \& Novyanti, 2000. Kata Sapaan Bahasa Minangkabau di Kabupaten Agam.

Jakarta: Pusat Bahasa Departemen Pendidikan Nasional

Crystal, D. 1987. The Cambridge Encyclopedia of language.

Cambridge: Cambridge University Press

Depdikbud, 1988. Kamus Besar Bahasa Indonesia. Jakarta: Pembinaan dan Pengembangan Bahasa.

Emi Satriana. 2008 "Address Terms Used In A Kulisusu Language Speaking Family". Unpublished Thesis.

Halim, Amran. (ED). 1980. Politik Bahasa Nasional. Jakarta. Balai Pustaka.

Halliday, M.A.K. 1985. An Introduction to Functional Grammar. Deakan University. London

Halliday, M.A.K. and Hasan R, 1985. Language, context and text. Deakan University. London.

Kamal, Mustapa, dkk. 1990. Sistem Sapaan Bahasa Iban. Jakarta : Pusat Pembinaan dan Pengembangan Bahasa.

Kaufman, Daniel. "South Sulawesi pronominal clitics: Form, function and position." Studies in Philippine languages and cultures 17 (2008): 13-65.

Kridalaksana, Harimurti. 1983. Kamus Linguistik. Jakarta. PT. Gramedia. 
Muzamil. 1997. Sistim Sapaan Baha Melayu Sambas. Jakarta Pusat Pembinaan dan Pengembangan Bahasa

Mahmud, Murni. "Politeness Practices In Bugis Society." Kajian Linguistik dan Sastra 23.1 (2011): 19-29.

Pateda, Mansoer. 1988. Linguistik (Sebuah pengantar). Bandung. Angkasa.

Sibarani, Robert. 1992. Hakikat Bahasa. Bandung. PT. Citra Aditya Bakti.

Sitti Alijah. 2016. "Kekerabatan Bahasa Bugis Dan Bahasa Muna". Unpublished Thesis.

Wardhaugh, Ronal.1986. an introduction to linguistic. Oxford: Brazil.

Yenni Wabula. 2005 The Use Of Terms Of Address In Cia-Cia Language. Unpublished Thesis.

Yuliana. 2005 "Address Terms In Konawe Dialectof Tolaki Language". Unpublished Thesis. 